\title{
Subtype Code
}

National Cancer Institute

\section{Source}

National Cancer Institute. Subtype Code. NCI Thesaurus. Code C93688.

A coded value specifying a further classification of type. 